\begin{abstract}
"They'll think I'm an Indian, won't they?":
Colonial Capitalism and Primitivist Fantasy in Tierra del Fuego, 18321996
\end{abstract}

\title{
Paul Magee
}

"The Philco Time Capsule" the inscription read, "Not to be opened until the 2nd of October, in the year 2492." I was staring at myself, at the reflection cast back by a black marble pyramid, an ungainly civic monument cast up on the foreshore at Ushuaia, the capital of Argentinean Tierra del Fuego, the rhetorical end of the world. The pyramid was flanked by a statue to the Ona, one of the four indigenous groups who lived in the region prior to the main white invasion in the 1880s. In the ensuing sixty years almost all of these peoples were exterminated, while their land was repopulated with colonists and sheep. The Time Capsule, I read on, contained six video laser discs, recorded with three months of television broadcasts from late 1992, along with the messages of five hundred Argentineans: "This material was made to last five hundred years, to show to the world of the future a part of the life and thought of our era." Why does the present, I wondered, need a pyramid, an orientalist icon of colonial conquest as much as ancient mystery; to encapsulate the message it sends to the future (a pyramid that, the inscription continued, "when the Twentieth Century has become but a rumour, will stand here like a traveller through time")?

Doesn't this time capsule represent a fantasy of the present's colonisation by the future, a fantasy to be realised in 2492 , to coincide with the millennium of American conquest, when an ancient culture - that is the present, the Argentinean Tierra del Fuego of 1992 - will finally reveal its mysteries? This is the realm of the future perfect tense, the "I shall have been." For under the imaginary gaze of its future conquistadores, the Fuegian present turns into the future's past. And in this same movement, the Reconquista of 2492, the white inhabitants of modern Ushuaia, as much as the video technology embodying them, suddenly become primitive. I am suggesting that the Philco Time Capsule, this "traveller in time," is actually travelling backward, not forward, availing itself of the future's imaginary gaze to place contemporary Tierra del Fuego into the past. Note how, in this process, the time-travelling pyramid has changed from being the subject of its own representation to the object of the future's observations. This is a profoundly colonial scenario.

To be another's object in another's past. Why would the Argentinean state, allied with Philco, one of the largest manufacturers in Tierra del Fuego, set up a fantasy scenario that positions the hegemonic subject in the same position as that allotted the native in traditional anthropological discourse? Such are the terms of Johannes Fabian's famous critique: "anthropology makes its object" through the deployment of temporally charged categories like "civilised" and 
"primitive" (more recently: "developed" and "underdeveloped"); such terms invoke an universal and all-inclusive temporal framework, yet leave the other no place of their own; they literally become our past, which makes it, by implication, their job to catch up with us. ${ }^{1}$ In this fashion, Fabian argues that anthropology - with its "denial of coevalness" to the indigenous other, its "allochronism" - has acted in the service of colonialism to deny its others the fruits of the present. ${ }^{2}$ In the present paper, I am not seeking to problematise Fabian's argument so much as to understand why a hegemonic and civilised power would want, through these temporal mechanisms, to project itself as primitive.

\section{THE “WORLD'S MOST PRIMITIVE INHHABITANTS”}

Tierra del Fuego is a perfect site for investigating such fantasies of colonial inversion because it has long figured as the home of the "world's most primitive inhabitants." Settled some ten thousand years ago by the people who would go on to become the Selk'nam (also named Ona), the Haush, the Yamana (also named Yaghan) and the Alakaluf, the island received its first white visitors in 1519. Ferdinand Magellan docked briefly on the North shores of what is now the Chilean Tierra del Fuego, and in the process gave the island its current name. After a disastrous attempt to colonise the northern shore of the Straits of Magellan in the late sixteenth century, and until the 1850 's, when British missionaries succeeded in establishing a settlement at Ushuaia, European visits were few and far between. The most well-known of these visits was of course that of Charles Darwin whose famously harsh 1832 judgement of the island's inhabitants ("I believe if the world was searched no lower grade of man could be found" 3 ) served, more than any other factor, to establish the Fuegian Indians' "world's most primitive" status. This status, ramified through the mechanisms Fabian describes, drove anthropologists and travellers to Tierra del Fuego in the desire to experience "a vista of life in Europe ... many thousand years ago." I I am citing from Samuel K. Lothrop's 1928 ethnography; one finds echoes of these sentiments in the 1929 fieldnotes of Sir Baldwin Spencer, who sought, likewise, to visit the Fuegians and so learn all the more about us. ${ }^{5}$ Their present is our past. The desire to see us at our most primitive has informed not merely the scientific record, ${ }^{6}$ but writings and travels in a variety of different genres, from H.G. Wells 1886 "scientific romance" War of the Worlds, right up to Bruce Chatwin's 1977 travel book, In Patagonia, both of which I shall analyse below.?

Beginning in the 1880's, with the onslaught of commercial colonisation by a variety of Argentinean, Chilean, and British sheep farming interests, the Fuegian Indian population declined dramatically, due to their slaughter at the hands of white colonists, and to the diseases the whites brought in their wake. The numbers of self-identifying Fuegian Indians is now minuscule (i.e. under 
ten, in a population of some 150,000 ). Most of this extermination had already taken place by the late 1920's, when Lothrop and Spencer wrote. So the imputation of "world's most primitive" status to the Fuegian Indians has a certain guilty edge to it as well.

\section{COUNTER-COLONIAL RHETORIC?}

Starting then, with the image of a black marble pyramid, casting back my own reflection in the sub-Antarctic sunlight, I am going to take this thoroughly textualised figure of Tierra del Fuego as my site for exploring fantasies of colonial inversion. I have already described one inversion of the civilised/primitive schema in the pyramid above: the white colonist of the present who is discovered in 2492 and thus made primitive by the conquistadores of the future. To further understand what is at stake in such manoeuvres I shall proceed to question the inversion involved in the idea of counter-colonial discourse, the gesture by which the civilised are suddenly made to seem the true savages of colonial history. It is hard, on the face of things, to disagree that the whites were the true savages in Tierra del Fuego. Yet there is more, I will suggest, to such reversals than what meets the eye in a simple mirror reflection. Questioning the Fuegian archive in this fashion will lead me to argue that such primitivisations of the present, and the inversions which usher them in, set the framework for the revelation of certain social fantasies tied up in what Karl Marx described as the "fetishistic character of commodities."

My reason for attempting to track down such colonial inversions lies in my desire to explore political strategies for anti-colonial writing, strategies for reversing the historical schemata that understand the genocide of indigenous people in Tierra del Fuego in terms of "civilisation" and "progress." The very fieldwork upon which I have based this paper was carried out under the rubric of reversal - that is, I was seeking to write an ethnohistory, not of the few surviving Fuegian Indians, but rather of their white colonists, travellers, and tourists. My incentive for anthropologising the whites was inspired by the realisation that many of the ethnographical comments made by colonists in Tierra del Fuego about the various Indian tribes referred far more appropriately to the whites themselves. In 1899, for instance, José Menéndez, one of the earliest colonists of Tierra del Fuego and by then one of the richest men in South America, described the Indians he had spent twenty years murdering and robbing of their land: "The Ona Indians are unbelievably rapacious .... They steal for the pleasure of stealing and they destroy foreign property." It does not take much perspicacity to see that the real "savage" was Menéndez himself, stealing land, destroying foreign property, murdering innocent people. Indeed, such an insight would fall well within the common counter-colonial rhetoric that directs the slur of native cannibalism back upon the colonist, and now neo- 
colonist. ${ }^{10}$ In the critical literature on Tierra del Fuego, the suggestion that the white capitalists eating up Fuegian land to populate it with sheep were the true cannibals they accused their victims of being has almost reached the level of a commonplace. ${ }^{11}$ Indeed, the very diffusion of this trope prompts me to question just what might be at stake in it.

One recent and well-known site for this reversal of the typical colonial dispensation of civility and savagery in Tierra del Fuego is Bruce Chatwin's postmodernish travel novel, In Patagonia. In the context of a lengthy and brutal account of the barbarity of white colonisation in Tierra del Fuego, Chatwin describes his incidental meeting, while crossing the Beagle Channel, with "a big man with a blotchy red face," an entrepreneur, down from Santiago "to see about a plant for processing krill." 12 Chatwin has just come from a pathos-ridden meeting with Grandpa Felippe, "the last of the Yaghans" (not that he was the last; but then, Chatwin is a traveller, ever searching for the best anecdote). Still shaken by the stories he has just heard of the Fuegian genocide, the jokes Chatwin now hears from this fat white man of money about indigenous cannibalism (" 'He probably ate them,' the fat man said," of Grandpa Felippe, and in reference to the long-lost ancestors Chatwin is tracking down in Tierra del Fuego ${ }^{13}$ ) become ironic pointers to the true identity of the capitalist, with his "plant for processing krill," as the cannibal he accuses others of being.

What intrigues me about this neat reversal of colonial thetoric is how the imputation of white barbarism (colonial capitalism as cannibalism) has, just like the Philco Time Capsule, the side-effect of primitivising Chatwin's broader presentation of the Tierra del Fuego of the present. He writes, in a neighbouring chapter, of the origin of the island's name, describing how Magellan, passing through the Straits, saw Indian camp fires along the shore and thus called the island Tierra ("Land") del Fuego ("of Fire"). Chatwin laconically drifts back from this historical anecdote and into the present tense of his voyage: "The Fuegians are all dead and all the fires snuffed out. Only the flares of oil rigs cast a pall over the night sky." 14 The suggestion of a tropic continuity between Indian fires and modern oil rigs is ironic, which is to say it occurs within a space more akin to fantasy than realism. Yet is this not similar to the space enshrined within the Philco Time Capsule, which, by imaginary reference to the colonial future, primitivises not merely the white Fuegian subjects of the present, but their tools and technology as well? For the laser disks it contains, seen in this (campfire) light, suddenly reveals their pyramidal role as magic native engravings, video embodied souls of the dead. And if the inversion implicit in the Philco Time Capsule, the positioning of the white as colonised, serves by association to primitivise white video technology, I think it can be argued that something similar is happening within Chatwin's text. For all the web of analogies through which whites are presented by Chatwin as the 
true savages, leads, by association and homology, to the primitivisation of the white production process too. It may be that the prime force behind such primitivisations of white culture, are our strange intimations as to the primitivity of modern technology. For the two reversals I have here considered could be read as "End of the World" sites for the expression of certain connotations of primitivism and fetishism that attach themselves to the tools, technology, and things most usually said to betoken progress, modernity, and civilisation.

\section{THE FETISH OF COMMODITIES}

In suggesting this, I am following a tradition of reading Marx's metaphor of commodity fetishism as far more than simply a colourful phrase adopted for rhetorical purposes. To trace how the fetish can be seen to find itself within fantasies of colonial inversion will require a slight digression. This digression will also serve to underline how radically my approach to this material differs from the Foucauldian discourse theory so prevalent in the Humanities and Social Sciences today, which can detect truth-functions (on the assumption - a dubious one, the moment you leave the earnest world of the university - that the search for truth is what really drives us through our lives ${ }^{15}$ ) but has nothing to say about the material processes leading to the fantastic, and scarcely believable, texts one finds again and again in the Fuegian field and archive.

In Marx's formulation, the fetish lies in the fact that within a capitalist economy, labour effectively functions as a property of the commodities it produces, rather than the humans who perform it. Commodities "confront each other," where human beings did previously, because in a fully fledged capitalist economy the production, exchange, and consumption of commodities is not only regulated, but even driven, by their function as magnitudes of homogenous units of commodified labour. ${ }^{16}$ The value of a given commodity (which we access through the related if illusory mechanism of its price) has nothing to do with its human desirability; it is a register of the amount of human labour that, on the average, went into its production. Witness how cheap products become (assuming the absence of monopoly) the moment you automate the labour that previously went into them. Yet the centrality of labour to capitalism manifests in a strangely abstract way. For in capitalism, the socially mediating nature of work relations takes on a transcendental character that is seen to attach to the body of the commodity in the form of its value. This occurs even though such value clearly has "nothing whatever to do with the physical properties of the commodities," nor their desirability. ${ }^{17}$ Value is a property of the commodity, and no longer a measure of its subjective import, while the surplus value (the excess generated by the productive power of labour, a function constitutively disregarded by the concomitant relegation of labour to commodity status, as just one more item among many) is expropriated by the capitalist as profit. This 
alienation of the worker facilitates the social interaction of things, much more than people, and has as its telos the accumulation of ever greater stores of value, much more than the satisfaction of social needs or desires. That is why unemployment remains, indeed increases as, a social problem when it should be a cause for rejoicing. We no longer need or desire to produce so much; but our societies are irrationally anchored to systems of valorisation predicated upon the commodification of labour. The things themselves tell us what to do. We work for them.

In describing this social confrontation of things, taking place over and above the meeting of their makers, who are reduced to thing like status in the process, Marx presents the scenario whereby, effectively, "things ... control them, instead of being controlled by them." 18 He finds the best analogy for this animation and indeed empowerment of the commodity within the anthropological notion of fetishism, where "the products of the human mind become independent shapes, endowed with lives of their own and able to enter into relations with men and women." 19

However Marx may have intended the status of this sardonic metaphor, I think that one can claim a certain phantasmic objectivity for it. Such an objectivity becomes apparent in those collective representations through which the invisible fantasies structuring social reality manifest themselves. ${ }^{20}$ So for Walter Benjamin the fetish metaphor takes on a strikingly material presence within nineteenth-century Europe, at the various World Exhibitions, where the mesmerising "cult of commodities," contrasts so strangely with the triumphant rhetoric of progress and modernity. ${ }^{21}$ Civilisation reveals its primitivistic character in the "phantasmagoria of capitalist culture," while "fashion provides the ritual according to which the commodity fetish wishes to be worshipped."22 As Michael Taussig notes, in Mimesis and Alterity, "it was in the representation of commodities in popular culture that the primitivism of modernity surfaced with unquenchable energy."23

This civilised primitivism surfaces in popular representations of the appearance of modern commodities amid primitive cultures. Taussig refers to the rash of colonial first contact vignettes wherein natives are represented as amazed at the "white man's magic" embodied in new commercial technology such as the phonograph. ${ }^{24}$ Taussig connects the fetishistic and spectral life of the commodity thus revealed with its correlate, the visceral mode of sensuous perception engaged by the modern mimetic machinery which channels these commodities to the market. What is apparent, in the "white man's fascination with their fascination with these mimetically capacious machines," is the way the "primitives" serve to manifest for the "civilised" the fetishistic magic that structures the very reality of capitalist interaction, an outwardly projected "civilised" magic, which is just as swiftly mis-recognised as the cultural property of the other. ${ }^{25}$ 
For my purposes here, what is important in Taussig's work is the idea that certain salient and structuring fantasies as to the fetish power of modern commodities and technology not only exist, in a phantasmic, yet material sense, but further, that they fuel activities and representations, most particularly within those first contact sites where one's own fetishism can be fantastically imagined through the eyes of the other. At the same time, I want to make it clear that such a materialist reading of the commodity fetishism metaphor has little to do with any Baudrillardian economics of consumerist desire ${ }^{26}$ I am talking of the fantasy within the commodity form, as it structures itself in the process of production and then manifests in social representations, irrespective of one's desire, conscious or otherwise, to consume. Nor, as I stated above, does this reading of commodity fetishism have anything in common with any theory of social discourse which would seek to understand textual productions in terms of their positive functioning in a network of power/knowledge. A fantastic manifestation like the Philco pyramid does not really represent anything to anyone, but is simply cast up as an excretion of the social body. An object of public indifference, it exists, outside any function or need, as an unread and largely useless manifestation of the fetishist metaphor at the heart of modernity itself.

Through these disclaimers, I distance my approach from that of Lamont Lindstrom, who, in his book Cargo Cult, Strange Stories of Desire from Melanesia and Beyond, utilises a similar archive, and indeed a similar strategy of ethnographic inversion, to read the colonial commodity anecdote as a discursive site for reflecting back to the colonist the universalisation of his own consumerist desires. ${ }^{27}$ On the contrary, I think that mirrors do much more than simply reflect, and it is this which further causes me to problematise the Chatwinian strategy of anti-colonial reversal, where the white is suddenly made the real savage. I suspect that the true revelation lies in the associated primitivisation of white technology, the fantasy that a modern oil rig is of the same nature as a Fuegian fire, just as a video laser disk is an ancient mystery to be found within a pyramid. That is to say, such an anti-colonial approach as Chatwin's may simply buy into the magic of modernity much more than contest the brutality it empowers.

\section{THE WAR OF THE WORLDS}

That the issue might lie in the primitivistic nature of such a modernity becomes clearer when we turn to the Tierra del Fuego of Charles Darwin, who discovered, in his visit there in 1832, not only the "world's most primitive inhabitants" but also the so curiously capitalist doctrine of the survival of the fittest. Darwin thus committed one of the grandest inversions of all; in Marx's words: 
Darwin recognises among beasts and plants his English society with its division of labour, competition, opening up of new markets, "inventions" and Malthusian "struggle for existence." 28

Which is why, in illustration of the various ideas and arguments about fetishism and colonial inversion above, I want to turn to a novel about England, the country (with "its division of labour, competition, opening up of new markets ...") which Darwin discovered in Tierra del Fuego. I want to turn to a novel which fantasises what England would be like if it were in fact colonised like Tierra del Fuego.

Some sixty years after Darwin's visit, at the same time that José Menéndez was accusing the Fuegian Indians of being himself, H. G. Wells, a Darwinian taught by T. H. Huxley, found the inspiration for War of the Worlds in an article in London's Daily News in 1882, which read as follows:

It is thought that the country of Tierra del Fuego would prove suitable for cattle breeding, but the only drawback to this plan is that to all appearances it would be necessary to exterminate the Fuegians. ${ }^{29}$

Reading such a blithe advertisement for genocide led the socialist Wells to fantasise how it might be if this situation were reversed. This became the plot of War of the Worlds, which describes how the technologically superior Martians invade England, demolish home county civility, devastate Britain, and come to the point of conquering the whole world.

In this manner, Wells shows his contemporaries a mirror of their own colonial savagery, at the same time as forcing them to imagine how it might feel to be colonised by a superior civilisation, a race whose "mathematical learning is evidently far in excess of ours" 30 .

[W]e must remember what ruthless and utter destruction our own species has wrought, not only upon animals, such as the vanished bison and the dodo, but upon its inferior races. The Tasmanians, in spite of their human likeness, were entirely swept out of existence in a war of extermination waged by European immigrants in the space of fifty years. ${ }^{31}$

The Tasmanians and the Fuegians have been frequently analogised as the world's most primitive peoples. Hence it is not surprising that, in Wells' fantastic reversal, the Martians/Civilised are presented as cannibals. Indeed, it is in search of food that they come to Earth. And they wreak ruthless and utter 
destruction upon the British/Primitives. Much of the rhetorical power of War of the Worlds lies in Wells' death's head manner of tearing British tradition, status, and pomp to pieces as men and women of all classes are suddenly turned into food for their new masters. In the ensuing mass panic, the humans themselves enact the violence that sees stores broken into, class distinctions dissolved, and money made meaningless. "As they grew hungry the rights of property ceased to be regarded." 32

Yet while the Martian heat ray seems to scorch civil society into the Earth, the explanation for the invasion is thoroughly grounded in the ideologies of nineteenth-century British society. "The intellectual side of man," Wells writes, "already admits that life is an incessant struggle for existence, and it would seem that this too is the belief of the minds upon Mars." ${ }^{3}$ The Martians, he continues, invade Earth to escape cosmic entropy, the inevitable cooling of their planet as the Sun dies out and "to carry warfare sunward" becomes their only means of maintaining the race. ${ }^{34}$ To them, we are "inferior animals" like the bison or the dodo, "inferior races" like the Tasmanians, less fit, that is, for the battle over resources that is survival. Which is as much as to say that the annihilating gaze that Wells turns upon Britain makes the ground degree zero of human nature one of the most profound ideologies of the culture it supposedly annihilates.

As for Wells' deus ex machina, or perhaps more accurately, deus ex biologia - the bacteria that finally kills the Martians/Civilised is itself little more than the exception which proves that the rule of Darwinism extends into outer space. ${ }^{35}$ (In point of fact, the greater part of the Fuegian genocide was caused by sexual and pulmonary diseases brought by the colonisers themselves. ${ }^{36}$ ) Of course an historical reading of Tierra del Fuegian colonisation quickly defeats any analogy between that process and a natural struggle for existence in the face of diminishing resources. For it was the very irrationality and artificiality of increasingly globalized food production processes that made possible the appearance of cans of processed Fuegian meat on British dining tables - hardly a necessity for European survival, though definitely a cause for the impossible struggle to survive forced upon the Indians. Similarly, it was the thoroughly social and artificial distribution of land resources in Chile and Argentina which provided the "natural" struggle for existence that drove poor colonists down South to work as peons on properties like those of José Menéndez.

Yet such an appeal to the historical reality which Wells ignores would be just as blind if it were to ignore the fantastic underside to the Darwinism which Wells professes and which we find so wrong. For if Wells thus reifies as nature certain ideologies of social interaction within his own culture, such Darwinian projections have the side effect of empowering the strikingly fetishistic images of Martian/Civilised technology throughout War of the Worlds. In such a fantasy space Darwinian evolutionism and fantasies of white primitivism empow- 
er each other.

Look at how Wells' text reveals the nature of colonial technology, as he describes the Martians, these "monstrous beings of metal," descending upon the Home Counties. Under the imaginary gaze of technologically backward British/Primitive eyes the Martians/Civilised seem as much machine as animal:

Were they intelligent mechanisms? Such a thing I felt was impossible. Or did the Martians sit within each, ruling, directing, using, much as a man's brain sits and rules in his body? I began to compare the things to human machines, to ask myself for the first time in my life how an ironclad or a steam engine would seem to an intelligent lower animal. ${ }^{37}$

While the analogy between the colonised and an "intelligent lower animal" is here striking, and strikingly repugnant (as is Darwin's similar comment on the Fuegians: "It is a common subject of conjecture, what pleasure in life some of the less gifted animals can enjoy? How much more seasonably it may be asked with respect to these men") ${ }^{38}$ it is, I am arguing, even more instructive to see how, from this fantasised British/Primitive/"lower animal" perspective, Martian/Civilised technology takes on such an animalistic and animated character.

The Martians hatch from capsules that seem like eggs buried in the flesh of the Earth. After some hours gestation, they suddenly appear as slug-like creatures within the massive "walking machines" to which they hence become metonymically linked. ${ }^{39}$ From these machines, which sound almost like the oil rigs Chatwin finds in Tierra del Fuego a century later, the "death ray," an "invisible yet intensely heated finger" of fire, shoots forth. It's a curiously corporeal weapon, perhaps recalling the animistic connotations of the word "firearms." 40 Indeed, these "vast spider-like machines," for all their mathematical superiority, are actually, in Wells' British/Primitive eyes, walking fetishes. ${ }^{41}$ When hiding next to a hatching Martian pod, Wells mistakes a Martian "handling machine" for an actual Martian, and he stresses the "living quality" of that "crab like creature with a glittering integument." He only realises "the true nature of this dexterous workman," that is, the crab's robotic nature, on seeing some real Martians, slug-like things that they are, lying around behind it. ${ }^{42}$ Wells is fascinated by the mechanical crab, by its "sort of sham musculature," its "curious parallelism to animal motions"; indeed "it seemed infinitely more alive than the actual Martians." 43

This, remember, is how Wells imagines European technology ("an ironclad or a steam engine") would seem to a member of "an inferior race." For the Martians were sent from the future to show how advanced technology appears to the primitive race that is the British. Note how the response from the past, 
this primitive and confused British description of Martians mistaken for their machines, echoes Marx's analysis of the fetishism of the commodity, where products of human labour "become independent shapes endowed with lives of their own, and able to enter into relations with men and women." 44 For human labour, read Martian. What is at issue here, in this revelation of the nature of colonial capitalism is not, to repeat, the "discourse" of Darwinism, but rather the fantasy which it facilitates. For the side effect of, and I am arguing, the real impetus behind, Wells' counter-colonial strategy of primitivising the British, is the way this manoeuvre allows him to fetishise the coloniser's advanced technology and things.

\section{THE PRIMITIVITY OF THE FUTURE}

Accounts of a native fetishism of Western things are surprisingly common within the literatures of geographically and temporally disparate colonialisms. Indeed, Wells' project of showing how he imagines we and our things would look through native eyes (which is to say, as explicitly fetishised as they are implicitly within capitalism) has almost the status of a colonial trope. ${ }^{45}$ It is perhaps enough to point to the well-known South African film, The Gods Must be Crazy, where a group of Bushmen (again, the "world's most primitive inhabitants") finds, and fetishes, a magic coke bottle, not to mention a "big animal," i.e. a car, and even a "great flying bird," i.e. a plane. ${ }^{46}$ That such fetishism is a civilised projection is obvious when one considers the universality with which it encountered in such vastly different places, and War of the Worlds, which has it emanate from the birthplace of the Industrial Revolution, makes this even more obvious.

The fact that The Gods Must be Crazy replicates the same temporal structure, and indeed the same fantasy, as War of the Worlds (and the Philco time Capsule, and many of Chatwin's anecdotes) both reveals the projective nature of these things, and further highlights the ambiguity of colonial temporality. For such "allochronism," as Fabian calls it, may well be the structure of anthropology and imperialism's discursive domination, but it also functions as a mechanism for colonial inversion, a structure for the revelation of ideological fantasy; and the fantasy is by no means straightforward. For there is quite a paradox in Wells' strategy of having the present discern its own primitivity in the civilised future. The Martians, after all, appear strikingly primitive and uncivilised in War of the Worlds, not least for the fetishised bodiliness of their technology, marked, Wells stresses, by the absence of the wheel. ${ }^{47}$ In their persons they have evolved beyond clothing, and indeed sexual differentiation, while the gruesome description of their eating habits all seems to make them rather more like racist fantasies of primitive abjection than any self-projection into the progressivist future. One of the points of horror in Wells' narrative 


\section{Magee}

focuses upon the Martians' eyes, eyes "at once vital, intense, inhuman, crippled and monstrous," and what is most horrific about them is that, unlike the eyes of the Bushmen in The Gods Must be Crazy, they do not return our message, they give nothing back. ${ }^{48}$ It is intriguing to compare the horror that Wells' narrator evinces of not being looked at, with Darwin's Diary entries from his visit to Tierra del Fuego in 1832. Much of the disgust in Darwin's description of the Fuegians seems to reside in his inability to read their gaze. It strikes me that a great part of Darwin's reason for imputing "most primitive" status to the Fuegians lay in the extreme unease arising from his failure to comprehend whatever unpredictable intention or opinion was manifested in their eyes, be it simple destructive violence or overwhelming desire for Western things. ${ }^{49}$ Such ocular anxieties find a strange echo in Wells' description of the Martians. Doubtless his narrative has been overdetermined by his attempt to represent the face of the future alongside the face of horror, the latter being such an eminently colonial and primitivist production. And then there is the fact that "scientific romance," the nascent genre to which Wells contributed, had such debts to Gothic literature as well..$^{50}$

Yet I think that this contradiction - the Martians as the face of the future, as well as the face of primitivity - actually lies in a paradox constitutive to the Darwinism Wells so roundly professes. The increasing congruity Wells prophesied between evolution and science leads in the future to the increased embodiment of Martian technology. By the same token it leads to a greater congruity between Martian behaviour and the "incessant struggle for existence" which, in Europe, the "intellectual side of man already admits." Note the temporality implied in that "already," as if we are heading in the Martian direction, but still lag far behind. This time lag, our distance from the future, is registered in the artificiality of British society, the same artificiality which Wells seems to so revel in tearing to pieces, as the true nature of civilisation, the "survival of the fittest" is revealed. What is utterly bizarre here is that the Martians appear more primitive and more asocial than the British by the very fact that they are more civilised and more advanced than them. Indeed, this contradiction is constitutive to any sociological application of evolutionary principles. ${ }^{51}$ For how can the evolutionally superior, the race closer to nature and its laws of natural struggle, not at the same time appear the more primitive?

And this leads one to wonder whether War of the Worlds does not actually prove that the British, along with the Chileans and Argentineans, who together invaded Tierra del Fuego with their firearms and their sheep production factories - were in fact more primitive than the Fuegian Indians? 


\section{UNDER ALIEN EYES}

Having begun this paper with a Tierra del Fuegian time capsule that primitivists modern video technology from the perspective of the Reconquest of 2492, I have tried to explore what might be at stake in various rhetorics of countercolonial inversion. In the travel writing of Bruce Chatwin, and then much more thoroughly in the scientific romance of $\mathrm{H}$. G. Wells, I have attempted to illustrate the primitivisation of white technology that is the side effect of such reversals. In this light, such counter-colonial writing has appeared, paradoxically, as something much more like a shrine for the fetishistic fantasies at the heart of capitalism. Such fantasies rely for their expression on the same temporal disjunction between self and other which Johannes Fabian decries in Time and the Other. Yet when Fabian critiques words like "savagery" for their role in "marking temporal distancing," he assumes that the colonial power always wants to allot itself the position of the civilised present, an assumption which the texts I have considered turn on its head..$^{52}$ As the Philco Time Capsule shows, it only requires an imaginary addressee in the future to set the stage for a hegemonic return to the past, for the revelation of what Michael Taussig describes as "the surfacing of the 'primitive' within modernity as a direct result of modernity." 53

Now while I broadly agree with Fabian's project to suture the temporal gap between self and other through a philosophy of praxis, I think that this project should simultaneously involve a more thorough, and indeed more fantastic, investigation of the complexities of the temporal mechanisms through which colonialism makes its object, and makes itself, both as subject and object. One such investigation would involve the analysis of the various temporalities engaged within colonial scenarios which do not fit within the linear and allochronically inclined framework of past, present, and future. The redemptive temporality, for instance, underlying the Christian kidnapping and re-education of four Fuegian Indians by Darwin's commander, Captain Robert Fitzroy, is clearly of a very different order to that inspiring the researches of his more famous naturalist. The path I have charted here has, on the other hand, sought to show that within the very evolutionary, homogenising, and spatialised temporal schemata that Fabian decries as "allochronism" lie often unrecognised spaces for colonial self-fetishing, spaces whose fantastic power is made even more apparent by the counter-colonial gesture which would seek to reverse the hegemonic dispensation of civility and savagery.

Nor, I want to add, is such a progressive and exclusive temporality so easily abandoned in the move to praxis. For time infiltrates one's unsuspecting projects like an alien presence, a reflection in a pyramid even. The strength of Fabian's argument surely lies in his insistence that the problem of time is not ended at the point where social evolutionism is replaced with better science. Indeed, there is a unilinear narrative of historical progress in the very procla- 
mation of such a replacement, one equally and ineradicably present, as Meaghan Morris points out, in the "post" of the "Post-structuralism" that so triumphantly and progressively imagines it has transcended the progressivist structure of unilinear time. ${ }^{54}$

As a final comment, then, on both the inexorability and the complexity of these intrusions of time and of fantasy, I will return to my own project, my white ethnography of modern Tierra del Fuego. What follows is basically a travel tale, a Chatwinian anecdote recounting an experience from my field work in early 1996. This anecdote, as I have repeated it, has evoked a bemused response that causes me to wonder just what might be the power which ensures its continued circulation. I cite it, then, as a final illustration of the force of civilised primitivism.

In Chilean Tierra del Fuego, I'm buying an old man's time with boomerang lessons. It's a plastic trinket that I've brought from home. I'd never thought that it would serve for this. Not that he wants to tell me anything anyway, or answer any of my questions about what the whites thought of the Indians, how they looked upon the massacres or what they thought they were doing down here on another's land. Mr. MacDonald hurls the boomerang off into the sky a good throw. The endless sub-Antarctic afternoon bastes a dark luminescence into the barren landscape. We could be on the Moon.

I had been interviewing the seventy year old Mr. MacDonald, the child of Scottish immigrants to Tierra del Fuego, in the course of my ethnography of the white nomadic subject in his or her encounters with the "world's most primitive inhabitants." I don't know why I mentioned to Mr. MacDonald, during our desultory interview (he said that he was born too late to know anything about the Indians; they'd all died by then) that I had a boomerang with me. "And it really comes back?", he asked.

So I suddenly became the native expert, teaching the foreigner something of our plastic, factory-made, and stolen culture. But Mr. MacDonald was a real natural, and in a few throws could even outdo me. Afterwards, we sat down in the grass, and he began to ask me a few questions in that lilting Scottish accent:

'What do you think of these UFOs then? Have you ever seen one?'

'No.'

'I've seen a few, you know. There is life out there. There must be. We're from out there too you know - originally.'

He began telling me of a story he'd read in Reader's Digest, relating how someone had been taken on board by the aliens, who had done an experiment on the victim's throat. Apparently this was similar to a local UFO abduction, one which Mr. MacDonald knew, for a fact, to have occurred. Mind, he didn't 
think that the aliens would have done anything bad, just an experiment. They were, after all, he proceeded to say, more intelligent than us; surely a more intelligent being would do nothing bad. I realised that I was at last hearing an account, and a fantastic one at that, of race relations in Tierra del Fuego.

Imagine what it would be like, Mr. MacDonald began to joke, if the aliens abducted him while he was out throwing the boomerang. He jumped up, and suddenly assumed a boomerang-throwing pose, as if for the alien eyes above.

"They'll think I'm an Indian, won't they?"

\section{Notes}

1 Johannes Fabian, Time and the Other, How Anthropology Makes its Object (New York: Columbia, 1983), 39.

2 Ibid.

${ }^{3}$ Charles Darwin, Darwin's Diary of the Voyage of the H.M.S. Beagle, ed. N. Barrow (Cambridge: Cambridge University Press, 1934), 120.

${ }^{4}$ Samuel K. Lothrop, Indians of Tierra del Fuego (New York: Heye Foundation, 1928), 204.

${ }^{5}$ Spencer, famous for his fieldwork among the Aborigines (again, the "world's most primitive inhabitants") of the Australian Central Desert, came to Tierra del Fuego to seek out the analogies the Fuegians might offer. So there are really two ways in which he was trying to learn more about us - I write from Australia - both predicated upon the same recapitulationist (as in their present recapitulates our past) discourse. Sir Baldwin Spencer, Spencer's Last Journey: Being the Journal of an Expedition to Tierra del Fuego by the Late Sir Baldwin Spencer, with a Memoir, ed. R.R. Marrett and T.K. Penniman (Oxford: Clarendon Press, 1931).

6 The most authoritative, and fascinating, of the colonial ethnographies is Martin Gusinde, Los Indios de Tierra del Fuego: Resultado de mis Cuatro Expediciones en los Años 1918 hasta 1924, Organizados bajo los auspicios del Ministerio de Instrucción Publica de Chile, 3 vols., (Buenos Aires: Centro Argentino de Etnología Americana, 1982). Most authoritative of later ethnographic works, and offering a very different analytic model to the primitivist/ recapitulationist works considered here, is Anne Chapman, Drama and Power in a Hunting Society: The Selk'nam of Tierra del Fuego (Cambridge: Cambridge University Press, 1982). As for the history of the island, there is no text in English devoted solely to that purpose. The most authoritative of the Spanish language texts are: Juan Esteban Belza, En la Isla del Fuego, 4 vols., (Buenos Aires: Instituto de Investigaciones Históricas Tierra del Fuego, 1974) (for Argentinean Tierra del Fuego) and Beros Mateo Martinich, Historia de la Region Magallanica, 2 vols., (Punta Arenas: Universidad de Magallanes, 
1992) (for Chilean Tierra del Fuego). There is no text which considers the island as a historical unity, because it is divided - uneasily - between Argentina and Chile. The intriguing fault-line that runs through the historical record serves to remind that history, at least in its modern disciplinary practice, is thoroughly beholden to the contours of the nation-state. I discuss the nationalism of historical practice, and how it is revealed in the Fuegian archive, at length in the second part of my ethno-history of travellers in Tierra del Fuego: Paul Magee, From here to Tierra del Fuego (Champagne: University of Illinois Press, 2000), 117-167.

${ }^{7}$ H. G. Wells, War of the Worlds (New York: Signet, 1986). Bruce Chatwin, In Patagonia (London: Penguin, 1977). I analyse the literature on the island in greater depth in From Here to Tierra del Fuego, the first part of which features a lengthy consideration of the most famous and interesting text on Tierra del Fuego: E. Lucas Bridges, Uttermost Part of the Earth, Indians of Tierra del Fuego (New York: Dover, 1988). Born at Ushuaia in 1874 to missionary parents, and fluent in Yamana, Spanish and English, Bridges offers many anecdotes of the sort (native awe at the "white man's magic" as Bridges himself terms it, 284) that I consider in this article, in the course of his description of his childhood, youth and later adulthood in the company of the various Indians. ${ }^{8}$ Karl Marx, Capital, a Critique of Political Economy, vol. 1 (London: J.M. Dent, 1974), 43.

9 José Menéndez, interview in El Diario (Buenos Aires, 13 June 1899), quoted in José S. Perich, Extinción Indígena en la Patagonia (Punta Arenas: Impressos Horizonte, 1995), 115 [my translation].

10 Eg., JuanEscudero, "The Logic of Biosphere, the Logic of Capitalism Nutrition in Latin America," Review 14 (1991): 1-25; for a British version, see Paul Harrison, Inside the Third World, The Anatomy of Poverty, $2 \mathrm{~d}$ ed., (New York: Penguin, 1981). 273-9.

1 See for example the story of Monsieur Maistre, the "negociante de carne humana" ("trafficker in human flesh") as recounted in the text, long illegal in Chile, that serves as the locus classicus of the white savagery trope in Tierra del Fuego: José María Borrero, La Patagonia Trágica. Asesinatos, Pirateria y Esclavitud (Buenos Aires: Zagier y Urruty Publications, 1989), 25-7. For Borrero, a savage ironist, men like Menéndez far from being the "primeros pobladores," or "first populators" of the island, as the colonial histories would have it, were ("el verdadero calificativo" - "the true epithet") its "primeros despobladores," its "first depopulators. (28)"

${ }^{12}$ Chatwin, In Patagonia, 126.

13 Ibid.

${ }^{14}$ Ibid., 106.

${ }^{15}$ So Michel Foucault: "The political question ... is not error, illusion, alienated consciousness, or ideology; it is the truth itself." Michel Foucault, "Truth 
and Power" in The Foucault Reader: An Introduction to Foucault's Thought, ed. P. Rabinow (London: Penguin, 1984), 75.

${ }^{16}$ Marx, Capital, 11.

17 Ibid., 45.

18 Ibid., 48.

${ }^{19}$ Ibid.

${ }^{20}$ A similarly materialist reading of the social manifestations of the commodity form can be found in Alfred Sohn-Rethel, Intellectual and Manual Labour, a Critique of Epistemology (London: Macmillan, 1978). Sohn-Rethel finds the features of the Kantian transcendental subject pre-formed within the very structure of the exchange relation, and argues that Kant misrecognises their provenance in according them the status of a priori knowledge. Of course, for Sohn-Rethel they have this status, but for very different, historical and materialist, reasons (78). One might also think here of Durkheim's theory of knowledge and religion as "collective representations" of social structure, as expressed in Emile Durkheim, The Elementary Forms of the Religious Life (New York: Free Press, 1965). Michael Taussig's comments on the epistemology of the social sciences operate on a very similar level; see Michael Taussig, The Devil and Commodity Fetishism in Latin America (Chapel Hill: University of North Carolina Press, 1980). I am here advancing a similar argument, but in relation to the fetish itself; much as Taussig does when he turns to consider the fetishistic representations of capitalism that he finds among peasants undergoing proletarianisation in Bolivia and Peru. My focus, however, is on its modern, rather than "pre-capitalist" manifestations.

${ }^{21}$ Walter Benjamin, "Paris, Capital of the Nineteenth Century," in Reflections, ed. Peter Demetz (New York: Schocken Books, 1978), 153.

22 Ibid.

${ }^{23}$ Michael Taussig, Mimesis and Alterity, A Particular History of the Senses (New York: Routledge, 1992), 231.

24 Ibid., 193-235.

25 Ibid., 27.

${ }^{26}$ See, for instance, his "Fetishism and Ideology: the Semiological Reduction," in Jean Baudrillard, For a Critique of the Political Economy of the Sign (St Louis: Telos Press, 1981), 88-101.

${ }^{27}$ Lamont Lindstrom, Cargo Cult, Strange Stories of Desire from Melanesia and Beyond (Honolulu: University of Hawaii Press, 1993).

${ }^{28}$ Marx, Letter to Engels, quoted in Stephen Jay Gould, The Panda's Thumb, More Reflections in Natural History (New York: Penguin, 1980), 58-9.

${ }^{29}$ Anon., quoted in Taussig, Mimesis and Alterity, 86; For the link to Wells, see "Matanzas de Selk'nam," in Impactos (Punta Arenas, Feb 1990), 4-6.

${ }^{30}$ Wells, War of the Worlds, 5.

${ }^{31}$ Ibid. 
32 Ibid., 118.

${ }^{33}$ Ibid., 5.

${ }^{34} \mathrm{Ibid}$.

${ }^{35}$ I am grateful to Dom Pettman for pointing out the deus ex biologia.

${ }^{36}$ This fact does nothing to stop Isaac Asimov's extraordinary "postcolonial" reading of War of the Worlds. Asimov, obviously ignorant of the Fuegians' fate, argues that the disease which disrupted Martian colonisation can be read as a prophesy of the "virus of freedom" [sic!] which led to decolonisation this century! He claims, furthermore, that this virus came from the United States; few might disagree on that point. See the "Afterword" to the Signet edition cited above. In this light, see the execrable 1996 film Independence Day, in which the computer virus of freedom, also emanating from the United States, defeats the more advanced than us - but more primitive in appearance - aliens of the future. As if echoing Asimov, the U.S. president in the film sees fit to bestow the virus of independence on the rest of the world too.

${ }^{37}$ Wells, War of the Worlds, 51.

${ }^{38}$ Darwin, Darwin's Diary, 212.

${ }^{39}$ Wells, War of the Worlds, 50.

${ }^{40}$ Ibid., 30; 26.

${ }^{41}$ Ibid., 85.

42 Ibid., 139.

${ }^{43}$ Ibid., 146.

${ }^{44}$ Marx, Capital, 45.

${ }^{45}$ For further examples, see my article "Famous First Colonist Finds his Fetish at the Uttermost Part of the Earth," The Journal for the Psychoanalysis of Culture and Society, vol. 3, no. 2 (1998): 99-108.

${ }^{46}$ Jamie Uys, The Gods Must be Crazy (Johannesberg, 1987).

${ }^{47}$ The primitivity of the future is even more apparent in Wells equally famous The Time Machine, though here the inhabitants of the future are divided into a more traditionally binary opposition of good native (the Eloi who inhabit an albeit ignorant, but lotus-like paradise) and the Morlocks (hairy ape-like cannibals). H.G. Wells, The Time Machine in The Complete Science Fiction Treasury of H.G. Wells (New York: Knopf, 1934). This novel reverses the racial time-space co-ordinates of War of the Worlds. In the latter, movement through space (Mars to Earth, and, by analogy, England to Tierra del Fuego/Tasmania) is equivalent to movement through time, for it takes one from a space of civilisation to one primtivity, just like the "time machine" operations Fabian detects in imperialist anthropology (Time and the Other, 35). Whereas in The Time Machine, one's travels through time (the machine never moves geographically) serve to mirror the "decline" from civilisation to primitivity than an actual British traveller would experience on route to the "uttermost part of the Earth" (the British are replaced by various races, as we move from the civilised inhab- 
itants of the present to the primitives of the future). Which raises the same strange question: how can the future - for a novelist who believes in evolution - be more primitive than the past?

48 Wells, War of the Worlds, 21.

${ }^{49}$ Darwin, Darwin's Diary, 130-135; 211-217.

${ }^{50} \mathrm{I}$ am grateful to an anonymous reviewer for pointing this out.

${ }^{51}$ This paradox is, in evolutionary terms, that of "negative selection," the survival of the unfit within civilised societies. So early eugenicists like Francis Galton, for instance, were forced to run the paradoxical argument that while the power of the civilised derives from their natural selection as the "fittest," these same natural rulers need to invoke artificial breeding techniques to keep out the unfit (i.e. they need to make artificial interventions to keep society natural). See John C. Greene, "Darwin as a Social Evolutionist," in Science, Ideology and World View. Essays in the History of Evolutionary Ideas (Berkeley: University of California Press, 1981), 104-110. This same paradox appears in Darwin's diary entries for the time he spent in Tierra del Fuego, as I suggested in "Famous First Colonist" (111).

52 Fabian, Time and the Other, 75. In this respect see Richard Eves, "Going Troppo: Images of White Savagery, Degeneration and Race in Turn-of-theCentury Colonial Fictions of the Pacific" in The Politics of Knowledge: Science and Evolution in Asia and the Pacific, ed. M. Low and C. Dureau, Special Issue of History and Anthropology, vol. 11, nos. 2-3 (1999): 351-386. Eves deals with the issue of "white savagery" in the fictional work of Louis Becke and Jack London, the "poet of Darwinism," which texts serve to show "that in the Pacific one cannot retain one's cultural and racial identity without considerable and sustained effort." His researches parallel mine in pinpointing colonial identities that find themselves, in all their fluidity, on the other end of Fabian's allochronism.

${ }^{53}$ Taussig, Mimesis and Alterity, 20.

54 Meaghan Morris, "Metamorphoses at Sydney Tower," Australian Cultural History 10 (1991): 19-32. See further Dipesh Chakrabarty, "Marx after Marxism: History, Subalternity and Difference," Positions, vol. 2, no. 2 (1994): 446-63. 